JAKOB NORBERG

\title{
"Haushalten":
}

\section{The Economy of the Phrase in Peter Handke's Wunschloses Unglïck}

(Published in The German Quarterly 81.4, fall 2008)

Literature can give voice to the repressed and the silenced, or so we would like to think. Not the least, postcolonial critics have sensitized us to the ironies of literary and political representation. Those who endeavor to speak about and on behalf of the underprivileged are often conditioned by the socialization and education through which they have gained access to the public realm, and they may come to rely on perspectives and discourses that perpetuate the very exclusion they seek to counter. ${ }^{1}$ The wish to intercede as an advocate for a disadvantaged group may be driven by the lure of a supposedly unspoiled community, and a concomitant assumption of its helplessness - a mixture of exoticism and condescension that threatens to reinforce rather than unsettle prevailing hierarchies.

Peter Handke is an author who has continually, and very controversially, tried to speak for marginalized individuals or peoples. In his ongoing defense of a stigmatized Serbia, he has become almost too obvious a target for the critique of the presumptuousness and nostalgia that can sometimes inspire acts of representation. $\mathrm{He}$ appears as a figure with an inflated sense of vocation claiming to be in touch with an embattled people. ${ }^{2}$ But Handke, or at least an earlier version of him, never claimed to be exempt from existing structures of privilege and subordination. A relatively early work, Wunschloses Unglück, is a case in point. This 1972 novella seeks to remedy the inarticulacy of the subject it portrays, but comes to reflect on how it is bound to rehearse 
the cultural and linguistic patterns that produced and policed this inarticulacy in the first place. Indeed, the novella is not simply troubled by the "unavailability of a form uncompromised by everything it wants to escape" (Bewes 38); the predicament of inescapable complicity is its principal focus.

To begin with, Wunschloses Unglück can be read as a case study in the multiple repressive forces at work in the poor and patriarchal milieu of rural Austria; it records the interlocking dictates of custom and religion, the pressures of economic constraints and social norms, the stifling gender roles and their most brutal manifestation - the physical abuse of women. The central figure is the narrator's mother, whose suicide prompts him to reconstruct her life story in roughly chronological fashion, to the point of her complete psychological collapse. Denied a place outside the home and taught always to contain her wishes and desires, she tries to adapt her life to the scripts outlined by tradition and monitored by village gossip, all the while being systematically worn down by heavy housework and meager living conditions.

Pained by this fate, the narrator wants to speak about and for the deceased, and make her life story available in the public realm to which she never gained entrance. But despite the sense of purpose and urgency that drives the book, and the intimate knowledge that supports the veracity of the account, this ethical and literary mission must fail. The main textual problem of Wunschloses Unglück is in fact the narrator's involvement with the forces of repression that he aims to expose. As the narrator himself realizes, the mechanisms of control and integration that devastate the mother's life reach far into the domain of language: the battery of prohibitions and expectations that circumscribe a female life in the province are bound to linguistic molds such as facile 
proverbial expressions and conventional storylines, all of which crowd in upon the subject. Language is already arranged for the speakers into tight, easily memorized formulas that encapsulate judgments and attitudes, thereby aiding the enforcement of norms. These circulating "idioms and axioms" encode and disseminate an entire social education, which prescribes how to live and feel in the community (Varsava 120). Describing the social stratification of the province, for instance, the narrator of Wunschloses Unglück cites the ideals that govern the interaction: "Zumindest beim Vergnügen gab sich die ländliche Gesellschaft klassenlos, sofern man nur GEPFLEGT und LUSTIG UND FIDEL war" (54; Handke's emphasis).

The fact that language is organized into readily available phrases works against the mother, who is unable to escape her misery partly because she lacks the capacity to formulate a critical alternative. She cannot help but think and talk against herself, and so remains silenced even when she speaks. Yet the problem of an already occupied language also inflects the narrator's attempt to reconstruct his mother's fate. He is gradually forced to recognize his failure to extricate himself from the idiomatic and generic patterns that directed or even closed down the mother's search for an identity, and notices how his own writing too easily slips into the realm of the pre-formulated. There is a standard way in which a woman's life, the "Biographie eines Frauenlebens," is usually told, and its gravitational pull is not negligible (45); there are surprisingly strong conventions dictating the course and the tenor of the narrative.

It is far from certain, then, that the author of the mother's biography manages to keep a distance from her regimented linguistic environment. It even turns out that her life story is so imbricated in the speech patterns of her community that it remains accessible 
only through the language that she herself spoke and that indeed spoke her. ${ }^{3}$ The signs of potential complicity have led critics to extract from Wunschloses Unglück a general point about the conditions of writing: "Ehe man zu schreiben beginnt, gibt es eine Sprache, gibt es Codes, Begriffe, Schemata, Konventionen” (Nägele 388). The novella submits that language is never an entirely neutral surface, but a territory where innumerable routes have already been etched in, leading the writer along its lines. ${ }^{4}$

Although this interpretation offers a framework for reading the novella, it still suffers from a lack of specificity. Many critics note the central concern of Wunschloses Unglück, and yet they fail to elaborate on how the novella imagines and negotiates its own implication in the structures it wants to dismantle. As this article will argue, Handke's story in fact constructs a thorough account of how the problematic of pervasive social control is transposed to a textual level. Even if this previously neglected discourse does not necessarily compel us to overturn the theses of earlier commentators, it challenges and revises the abbreviated argumentation on which their conclusions are built. The narrator of Wunschloses Unglück does not simply fail to avoid involvement in the linguistic regime that confines the mother; with painstaking detail, he seeks to render this failure readable within the narrative itself.

The narrator's own elucidation of his linguistically apparent complicity is phrased in the idiom of economy; that is, it is treated in terms of a "relationship between ends and scarce means which have alternative uses" (Robbins 16). To begin with, Wunschloses Unglück sets up a relationship between the narrator's conditions of articulation and those of the mother. While the narrator and his central figure are not necessarily constrained by identical forces or shared motivations, their situations of speech and writing are 
nonetheless described as analogous. The suggested parallel between them is then most fully brought out in a discourse on the notion of household management, or "Haushalten," which entails the problem of how to allocate effort in a context of insufficient resources. For different reasons, the narrator and his main character come to rely on phraseology while negotiating the need to minimize expenditure of their limited means: their time, their attention, their labor..$^{5}$ In the process of constructing a model of domestic economy, Wunschloses Unglück uncovers and critiques an economy of the phrase that it must ultimately put into practice. The suspicion of complicity with repressive forces that haunts the enterprise of literary representation is thus explained, or perhaps excused, with reference to the problem of scarcity.

The novella's discourse on the formative power of budget constraints on text production can be reconstructed in a series of steps. After an initial analysis of the narrator's consistent description of the writing process in terms of an exertion of labor with a naturally limited duration, we must turn to his critical profile of the mother's social context and its continual demand to reduce waste. The concern of the final section is the relationship between these two threads: it investigates how the requirements of the writing process and the desire to expose an inhuman social environment must be reconciled in the work on the text. The narrator does not necessarily fail in his critique of his mother's repressive social world, but he claims that he must struggle to match his critical ambitions with the limited means at his disposal. The result is a textual strategy of quotation that appears both critical and collusive. 


\section{The Labor of Writing}

In Wunschloses Unglück, the narrator takes pains to outline the situation and character of writing, and his account ultimately bears upon the question of the precarious use of the deforming language that he sets out to analyze. The novella opens with a cited newspaper report, a one-sentence description of the mother's suicide that resembles a telegram. The quotation is not necessarily inserted with the critical intention of displaying how its stripped-down language cannot capture the full import of the mother's fate. ${ }^{6}$ The mere existence of the novella certainly implies that the circumstances of the death, or the motivations behind the suicide, can be described in more detail, but relative brevity is not in itself a defect. Wunschloses Unglück is, after all, a slim volume of about 100 pages, carrying the modest subtitle "Erzählung." The generic classification underscores the fictional status of what seems like an exercise in autobiography, but it also sets the text apart from grander epic forms; the book is not a full-length novel.

Rather than scorning the shorthand style of local newspapers or using it as a convenient foil, Handke's narrator goes on to indicate how the degree of concision of any text must be related to the conditions under which it was written, or how the length and detail of any narrative are functions of invested effort. The novella that follows upon the opening newspaper quotation shows that one can tell a different and significantly longer story of the deceased, but it also makes explicit that any such project requires considerably more labor. Immediately after the incorporated report, the narrator announces his resolution to start working, that is, to tell a more extensive story: "Ich möchte mich an die Arbeit machen" (7). 
In Wunschloses Unglück, the activity of writing is in fact consistently represented as a dynamic of labor expenditure; it is discussed in terms of an "Arbeitsanstrengung" (7). As an exertion of force, however, this activity cannot be sustained indefinitely, as if the writer's energy were endless. Instead, the periods of writing are inevitably interspersed with periods of restoration, producing a cyclical movement of work and rest. $^{7}$ In accordance with this definition, the text implicitly submits that its final shape, its rather limited expanse, is the outcome of an exertion of force pitted against obstacles and subject to ineluctable constraints. There is a window of writing, a restricted period during which the "Anstrengung" of the writer could be maintained before yielding to unavoidable exhaustion (10). At the end, this window of writing turns out to have been about two months long. A note placed after the final sentence of the narrative, states the duration of the entire writing process: "geschrieben Januar/Februar 1972" (106).

The definition of writing as labor is closely linked to the narrator's struggle to fend off the volatile sequences of apathy and horror, which beset him after the mother's suicide. To recall the past and formulate an account of it under such psychological conditions, to resist giving in to the speechlessness that accompanies both moments of dullness and dread, requires a strenuous application of mental force; the pressure of grief makes writing hard work. But the labor of writing also seems to have beneficial effects, for it works to pull together and focus a mind that threatens to lose itself in a series of numb or chaotic emotional states. The activity of attentive description even inserts an interval between the traumatizing event and the writing subject. When one describes a psychological state in as precise a manner as possible - "möglichst genau" - this state 
may seem "entrückt und vergangen," no longer threatening to engulf the subject, and in this way writing offers moments of relief (9-10).

In light of this positive effect of writing, the activity of narration may seem to emerge as a form of "Trauerarbeit" that serves the purpose of releasing the subject's affective ties to a lost object. ${ }^{8}$ The prospect of some final release is, however, overwhelmed by the cyclical model of labor, according to which constantly renewed efforts must be mustered to satisfy temporarily subsiding but ineradicable needs. The novella's dominant paradigm of labor is the never-ending toil of the housewife to deal with drearily recurrent problems. As the narrator's mother writes in a final letter before her suicide, she suffers from the eternal return typical of all domestic duties: "Jeden Tag mache ich dieselben Arbeiten, und in der Früh herrscht wieder Unordnung. Das ist ein ewiger Teufelskreis" (76). ${ }^{9}$

The activity of formulation may offer respite but it does not establish any lasting and conclusive relief, since, according to an account that resolutely codes writing as "Arbeit," it remains subject to the motions of repetitive labor. The writing process may separate off a course of events and converts it into a safely bounded past, but the desired distancing effect lasts only as long as the limited "Zeit des Schreibens" (10). Its merely temporary impact deprives writing of any permanent therapeutic value. ${ }^{10}$ The psychological state the narrator finds himself in allows for and can even be remedied by textual production, but the labor takes place during restricted periods of time, in surges that must come to an end and leave no durable results. In Wunschloses Unglück, "Trauerarbeit" is a form of "Arbeit" and hence restricted by its rhythm; it remains chained by the "relentless repetition" characteristic of any process of labor (Arendt 101). 
The final line of the novella - "Später werde ich über das alles Genaueres schreiben" - seems to contain a promise, made by the narrator to himself or to the reader, of a more exact account, delivered in a future where the emotional turmoil has settled and writing is no longer shadowed by speechlessness (105). At the same time, it concedes that the present labor of narrative reconstruction has dissolved the depression incompletely and that a future effort remains necessary. The assurance of a further, future account implies that it is the failing energy of the narrator that finally breaks off the activity of storytelling, rather than the logical conclusion of the plot or the exhaustive treatment of the material. Indeed, if the narrator emphatically describes his activity as labor, as "Arbeit" and "Anstrengung," then the novella's closing promise points to a later resumption of labor that must end in weariness. The final form of the delivered text, and the final form of any future, supplementary account, must be the product of a concentrated work effort that can postpone but not halt the eventual return to muteness, a work whose span is a function of the quantum of mobilized labor and whose end is the symptom of inevitable fatigue. The "Zeit des Schreibens" must always come to an end. The two enigmatic mottos of the "Erzählung," one drawn from Bob Dylan and one from Patricia Highsmith, also allude to the notion that writing must be conceived of in terms of urgent expenditure within a definite time frame. Rather than declaring some wisdom that would offer a key to a message embodied in the story, the strangely nonaphoristic quotations seem above all to point to the rushed character of the writing. Like the italicized remark at the very end of Wunschloses Unglück, the Highsmith citation names a month: "It was just after 7 p.m., and the month was October" (5). Yet the quotation's first line conveys a sense of swift pace, or of little time left: "Dusk was 
falling quickly." Similarly, the line culled from Dylan - "He not busy being born is busy dying" - may be read as a comment on the mother's fate, ${ }^{11}$ but it also captures the relation between compression and scarce means that runs through the narrator's discourse on writing. The shrunken, elliptical construction of the sentence conveys the hurried pace named in the repeated word "busy."

Wunschloses Unglück calls attention to the fact that the length and detail of any text is related to the invested labor effort, and that this effort cannot be continued without end. Against the backdrop of its characterization of the writing process, the novella is not simply a brief work; rather it is compressed, or shaped by conditions inherent to a process of writing understood as labor. To be sure, its brevity does not necessarily mean that it is imprecise. Nor is the style of the novella, on the level of the sentence, always terse: the narrator at least occasionally allows himself meandering constructions and extensive reflections on his writing practice in asides. However, by coding the writing process as labor and describing the cycles that this labor is governed by, the text explains its brevity with reference to the constraints imposed by limited resources. It presents itself as an account wrested out of an enveloping, approaching speechlessness, and thereby frames its admitted concision as a testimony to the situation under which it was produced. Regardless of its length, Wunschloses Unglück communicates, both by means of its discourse on writing and by various paratexts, that more could not be written, at least not at this point. 


\section{The Double Narrative}

The labor of writing, the "Arbeitsanstrengung" of the writer, entails recollection and formulation. The writer works on the material of past events. In the case of Wunschloses Unglück, this material proves recalcitrant; it resists his efforts of storytelling. On the most basic level, the mother's life is eventless, dominated by the monotony of never-ending work in the constricted domestic realm as well as the dreary dramaturgy of married life. But the story does produce, despite its brevity, something of a panorama of a turbulent century. Just by virtue of revisiting the handful of stations of the mother's life, it offers a condensed review of the pre- and postwar conditions as well as the period of National Socialism and war; the parochial agrarian province of Austria and the devastated city of Berlin after 1945; the first steps towards land ownership among a peasant population accustomed to feudal conditions; and the security mechanisms of the emerging welfare state, in which the poor are entitled to social benefits if they can plausibly demonstrate their lack of means. Still, the mother spends all her time in the sphere of the family household, constantly under pressure to keep expenses down and hence condemned to a "Leben nicht über die Verhältnisse" (57), making her life seem almost detached from the times, "ein altes Lied; ohne Beziehung zur Zeit, in der sie spielt." (58).

The central problem of the novella is indeed how a biography is fundamentally determined by the problem of minimal means, or how an "aufs Wirtschaften und pure Auskommen beschränkten Lebensform" results in a complex of psychosocial deformations (50). Not incidentally, the narrator begins his mother's story with an historical overview of the local property relations in the province where she grew up. Her 
father is introduced as the first homeowner in a long line of "Mittellosen," and yet since this advance remains modest, he is forced to spend all his labor power, "seine ganze Arbeitskraft," only to retain it (14). Whatever he earns he saves, to the point at which hoarding becomes the principle of his personality, since he represses every need and impulse to fit the cause of living without squander.

The life of the mother, shaped both by inherited attitudes and a similarly fragile economic situation, evolves into a perennial exercise in self-management or rather selfreduction. Her non-negotiable task is to monitor the small household, which means to endlessly perform the activity of "sparsames Umgehen mit knappen Mitteln zur Bedürfnisbefriedigung” (Egner 68). The narrator again and again relates how the mother applies the lessons of saving, becoming "kleinlich und haushälterisch" (37) in her approach to the use of objects, to the extent that her biography is best described in terms of "lebenslängliches Haushalten" (62). In a situation of severe shortage during the postwar period, where saving is no longer possible because one must live slightly above one's means in order to avoid starvation, the distinction between the necessary and the superfluous is even applied to basic needs, and the principle of self-reduction moves into the domain of vital human necessities, making a mockery of the ethical blessings of asceticism. Yet even during less desperate times, it is clear that the constraints of "Haushalten" pervades all social and emotional aspects of life, making it the medium for any manifestation of personality: expressions of spontaneity and defiance, for instance, assume the form of frivolous economic decisions. The narrator at one point reports the mother exclaiming "'Heute war ich leichtsinnig und habe mir eine Bluse gekauft” (54). 
Far from being a straightforward theme of the story, however, the practice of "Haushalten" generates a narrative predicament, for the mother's vigilant attention to costs is accompanied by strategies designed to foreclose enquiry and description. In addition to the problem of scraping by from day to day, the mother lives under the burden of having to perform this feat in a socially acceptable manner, of satisfying the standard of restrained and dignified behavior sanctioned by the community. The novella thus investigates how the economic conditions are overlaid with social requirements to impose the combined stress of constant pecuniary problems and norms regulating the response to these problems. According to the ideology of the society around her, the poverty under which the mother lives is not shameful as long as one measures up to the code of respectability most fully captured in the term "Sauberkeit" (59). Preserved cleanliness is the criterion with which one can distinguish between the retained serenity of "Armut" and the wretchedness of "Elend:" "Die Sauberkeit machte die Armen gesellschaftsfähig" $(59) .^{12}$

This effort to be clean, to hide the reality of family life behind a presentable screen and cover up any signs of destitution, is nothing but an attempt to forestall any negative descriptions, or any descriptions at all; “denn an der reinlichen, doch unverändert elenden Armut gibt es nichts zu beschreiben" (61). The narrator cites one of the maxim of cleanliness - "Das Fenster ist die Visitenkarte des Bewohners" - to show how the sanitized home is the result of a strenuous project to maintain the family reputation, which centrally involves reducing the number of stories that can be told about it (59). A narrative would, according to the expectation that guides this incessant cleaning, only grasp that which deviates from proper conduct, whereas "neat is a closed 
book" (Green F6). For the poor, to be out of the ordinary means to be marked by some flaw.

The "Anstrengung" of the writer to tell the story of his mother's life thus meets resistance in "die täglich neue Anstrengung, sein Gesicht zu behalten" that dominates this life (61-2). If he does produce a narrative that deviates from the polished manuscript that serves the purpose of keeping its subject within the circle of respectable society, then that must be a story of how the nervous management of impressions failed or of what it always hid. The narrative of Wunschloses Unglïck is therefore partly the unofficial story, or the story that escapes the mother in her effort to control what can be told about and her family. And this narrative is necessarily about weariness and desperation - that is $-\mathrm{a}$ narrative that notes and connects moments of failed "Anstrengung," recording the exhaustion and panic visible under the mask of "überangestrengter Würde" (37).

Wunschloses Unglück presents a divided account, in which the sanitized story of the mother, or rather the pre-articulated, socially approved version she tries her best to live up to, is supplemented with a report on the damage that it both shields and compounds. The necessarily split narrative sometimes even takes the manifest form of passages coordinating citation and commentary. The reader first receives the story that the mother tells herself, or the story she feels compelled to tell to maintain a degree of social acceptance, and then follows an alternative account, which emphasizes the physical and psychological costs of the life she and other women lead:

Keine Maschinen im Haus; alles wurde noch mit der Hand gemacht. Gegenstände aus einem vergangenen Jahrhundert, im allgemeinen Bewußtsein verklärt zu 
Erinnerungsstücken: nicht nur die Kaffeemühle, die ja ohnedies ein liebgewordenes Spielzeug war - auch die BEHÄBIGE Waschrumpel, der GEMÜTLICHE Feuerherd, die an allen Ecken geflickten LUSTIGEN Kochtöpfe, der GEFÄHRLICHE Schürhaken, der KECKE Leiterwagen, die TATENDURSTIGE Unkrautsichel, die von den RAUHBEINIGEN Scherenschleifern im Lauf der Jahre fast bis zur stumpfen Seite hin zerschliffenen BLITZBLANKEN Messer, der NECKISCHE Fingerhut, der TOLLPATSCHIGE Stopfpilz, das BULLIGE Bügeleisen, das für Abwechslung sorgte, indem es immer wieder zum Nachwärmen auf die Herdplatte gestellt wurde, und schließlich das GUTE STÜCK, die fuß- und handbetriebene 'Singer'Nähmaschine; - woran wieder nur die Aufzählung das heimeilige ist.

Aber eine andre Methode der Aufzählung wäre natürlich genauso idyllisch: die Rückenschmerzen; die an der Kochwäsche verbrühten, dann an der Wäscheleine rotgefrorenen Hände; - wie die gefrorene Wäsche beim Zusammenfalten krachte! -; ein Nasenbluten manchmal beim Aufrichten aus der gebückten Stellung; Frauen, so in Gedanken, alles nur ja schnell zu erledigen, daß sie mit dem gewissen Blutfleck hinten am Kleid selbstvergessen zum Einkaufen gingen; das ewige Gejammer über die kleinen Wehwehchen, geduldet, weil man schließlich nur eine Frau war; Frauen unter sich: kein 'Wie geht's?', sondern 'Geht's schon besser?’” (63-5).

Admittedly, quotation and commentary are not completely separated into consecutive clauses here; the sarcasm and regret is recognizable throughout the passage. 
Even so, the reader is presented with two distinct lists that pedagogically reveal what is repeatedly said and what is numbly experienced, the decorative expressions with which one tries to make oneself at home in the world, even to populate it with benevolent figures, and the daily chores which wear one down. Beyond the projection of life onto the use objects captured in a series of fixed attributions, the reader finds the routine work that the housewife has to carry out. The nostalgia the language may inspire is immediately dispersed by information that runs counter to any fantasy of a rustic life.

In the passage above, critical storytelling takes the form of juxtaposition, which makes manifest the two-track model implicit in the novella as a whole. Since the narrator is familiar with the already arranged versions of his mother's life, or since that story of homeliness constitutes a kind of verbal inheritance, he opts for a combined presentation where the already articulated account is closely shadowed by observations of experiences that have remained unexpressed. Symptomatically, the second paragraph containing the alternative account also notes a moment in which a façade is imperfectly maintained. The sign of exhaustion and physical ruin, the "Blutfleck" on the skirt, is carried out into the public by neglect. By relating the scene with the bloodstain, the narrator gestures to the stigma of womanhood in a community dominated by men: when the housewife enters a sphere outside the home, she carries the mark of her sex with her into a space generally reserved for the privileged gender. But the unnoticed stain also represents the failure to uphold the image of "Sauberkeit," to wash away all signs of decrepitude in the daily effort to remain presentable. The "other method," namely the added, alternative narrative that complements and exposes the happy list of animated household objects thus contains within itself a scene documenting the fouling of public surfaces. 
In a sense, the narrator's work begins where the mother's work ends, or where she lacks the strength to live up to the prescribed behavior of her community. The practice of the double narrative is then a critical method, a means to draw attention to the severity of the mother's conditions in a way that keeps a distance from them. The narrator does not resort to the phraseology of the mother and her environment, but exposes it by providing unsettling observations. Haunted by the imperative to economize, however, the double narrative is condensed to the point where the line between critique and complicity becomes increasingly difficult to trace.

\section{The Economies of the Phrase}

The text of Wunschloses Unglück is not always arranged into paragraphs that bring together the illusory but socially presentable account of a life and the observations that undercut it. The narrator knows more parsimonious means of disclosure than the rewriting of entire passages. In fact, the quotation above provides a sample of a common procedure of critical commentary, one that subverts the smooth discourse without relying on the attachment of additional paragraphs, but instead efficiently highlights the presence of ideology by means of a simple typographical manipulation. Nothing more than a change of script, the use of the upper case - "der GEMÜTLICHE Feuerherd" - is necessary to alert the reader to the fixed phrases of the world whose hidden, less jovial underside must be exposed.

This method is deployed throughout Wunschloses Unglück, from the first to the last page. When the narrator comments on the stereotypical distribution of roles in the 
mother's unhappy marriage, he notes: "Wenn er [the husband] betrunken war, wurde er FRECH, und sie mußte STRENG zu ihm werden" (35). During the period of National Socialist rule in Austria, a kitsch jargon also enters colloquial language, and the narrator tracks the introduction of this vocabulary with his favored technique: "die mit neuen Hoheitszeichen versehenen Gebäude bekamen STIRNSEITEN und GRÜSSTEN; die Wälder und die Berggipfel SCHMÜCKTEN SICH” (23).

As a critical procedure, this kind of ironic quotation has a long tradition in the context of Austrian literature. In his profile of Karl Kraus and his journal Die Fackel, Walter Benjamin points to the Viennese satirist's ability to deliver his opponents to ridicule by citing them: "Die Zitate der 'Fackel' sind mehr als Belegstellen: Requisiten von mimischen Entlarvungen durch den Zitierenden" (347). For Handke's narrator, then, the typographical measure by which to highlight the idioms brought into and thereby critically exhibited in his text does not represent a departure from the practice of the double narrative, of the continual coordination of citation and commentary. It is instead a more compressed version of it. By simple means, phrases are alienated from their textual surroundings, singled out for the reader's heightened scrutiny.

By inserting tagged phrases such as "LUSTIG UND FIEDEL" or the coupling "FRECH" and "STRENG" in the text, the reader's attention is directed toward samples of the stereotyped interaction or common attitudes to which the mother adapts. Such idioms constitute, one could say, the quotable aspect of social control. As such, they almost never issue from a single, easily identifiable source that can be focused on as an adversary in a polemical battle staged in a Kraussian manner. The idioms are not the expressions of a clearly contoured individual speaker; instead they represent what is said. 
The control that a common language helps enforce does not represent any active repression of one individual by a hostile group; instead it constitutes the linguistically mediated monitoring of society by its own members, the self-administered maintenance of repressive consensus within a collective. Wunschloses Unglück never shies away from portraying the mother's suffering, but it also never offers the reader a clear polarity between an individual victim and an indicted community. Through the close attention to a language used by everyone, including the mother, it shows how a person may involve herself in and support the processes of integration that she and others suffer from. The problem of linguistic repression does not allow for the easy identification of an outside culprit.

The novella repudiates any facile attributions of blame and instead investigates the complex mechanisms that ensure the hold of phraseology over the collective imagination. The social advantages of using widespread expressions are clear: while they often transmit values that are constricting and even debasing, especially to women, their use secures unproblematic belonging in an already defined community. They offer themselves to the speaker as established and shared formulations, the utterance of which will have a reliable resonance in the surrounding social field. To state these phrases, and to manage one's life in accordance with them, is to minimize the disapproval that can be provoked by one's speech and actions; it is a method to secure one's "Nicht-Auffallen" through careful behavioral adjustments (40). The mother lives her life under the "schiefe Blicke" of the community, the censorious glances cast at any woman who oversteps the boundary of proper female conduct until the feeling of shame is entirely internalized and no explicit penalizing response by the community is needed (32). By speaking the 
language of her tightly knit social networks, she tries to avoid the burden of condemnation. The widespread fear of being stigmatized, of being put out of harmony with society, guarantees uniformity of speech. ${ }^{13}$

There is, however, yet another advantage to reproducing available phraseology, one that more precisely explains the narrator's involvement with the language he subjects to scrutiny. Use of communal mini-texts whose often rhythmic and concise composition facilitate continued circulation also means saving effort. Phrases are strips of words already "set in order by someone else" and so they relieve the speaker or writer of further work (Orwell 426). ${ }^{14}$ Handke's narrator explains how pre-articulated phrases can be viewed as elements of a "Sprachfundus" or become stored in a "Formelvorrat," stacked away as a resource to which the thrifty speaker/writer can turn (45, my emphasis). Indeed, the "bereits verfügbaren Formulierungen" allow for the practice of "Haushalten" in the field of language and storytelling; they make up a supply to be drawn on when one is forced to speak or write in conditions of scarcity, to compose under the constraints of stress (45). Despite the narrator's critique of the linguistically supported social repression operating in the mother's provincial milieu, he is not immune to the convenience and ease of phraseology. For someone who repeatedly speaks of his "Schreibtätigkeit" as a kind of "Anstrengung," and who understands his writing in terms of the exhaustion and renewal of resources, linguistic formulas appear, with some qualifications, eminently usable (46). He does not avoid them altogether, but sifts through them to look for what can go into his work: 
Ich vergleiche also den allgemeinen Formelvorrat für die Biographie eines

Frauenlebens satzweise mit dem besonderen Leben meiner Mutter; aus den

Übereinstimmungen und Widersprüchlichkeiten ergibt sich dann die eigentliche Schreibtätigkeit. Wichtig ist nur, daß ich keine bloßen Zitate hinschreibe; die Sätze, auch wenn sie wie zitiert aussehen, dürfen in keinem Moment vergessen lassen, daß sie von jemand, zumindest für mich, Besonderem handelt - und nur dann, mit dem persönlichen, meinetwegen privaten Anlaß ganz fest und behutsam im Mittelpunkt, kämen sie mir auch brauchbar vor. (45-6)

This passage, drawn from one of the more extensive meta-poetical asides of the story, is not exactly a bold statement of the desire to revitalize a calcified language, to stay away from the domain of the pre-articulated. ${ }^{15}$ It is rather a cautious apology for tapping into the linguistic fund that is also the constant object of analytical attention. Although the narrator wishes to avoid mere quotation, the contents of the shared storage room of formulaic solutions are designated as generally "brauchbar." He is too opportunistic, or under too much pressure, not to take advantage of them.

As argued above, the many idioms, bits of jargon, and quotations strewn throughout the text and often highlighted by the use of the upper case are abbreviated and hence efficient exercises in language criticism. They signal the narrator's struggle to remain attentive to the rigid speech patterns of the mother's social environment, patterns that she occasionally tries to shield herself with, but which also harm her by imposing demands. Yet the insertion of pre-formulated expressions at the same time requires less effort. To quote critically in the way the narrator does is to relieve oneself of a textually 
extended analysis, even of the problem of inventive formulation. In this more defined way, we can speak of his problematic complicity with the language of the social context he seeks to expose. The typographically inflated phrases are best described in terms of a peculiar overlapping of linguistic economies, the one of the narrator and the one of the society under diagnosis. Easily memorized formulas can reduce the toil of independent articulation for the members of a language community, but they also become a laborsaving device for the writer, who ends up drawing on the "[V]orrat" to integrate those units of formulaic speech that seem useful to him. The economy of the phrase both facilitates and undermines the project of a critical biography.

Contrary to the mother, who, trained not to express herself and to sacrifice her needs or wishes, sinks into an increasingly mute condition of "[w]unschloses Unglück," the narrator feels compelled to write, to produce an account, and talks of "das Bedürfnis, über sie zu schreiben" (7). Yet this need threatens to dissolve into apathy, forcing him to apply himself, to expend his force and energy until it runs out and the storytelling must come to some end. Throughout this process, he criticizes and paradoxically also relies on the already-said, the once coined and hence available expressions. He cuts the costs of writing even in the very act of exposing stereotypical formulations. The text is thus not an author's display of unfettered imagination, mobilized to reinvigorate a frozen language, but the product of an exercise of "Haushalten" in the realm of writing. By installing the elaborate imagery of labor and storage in his characterization of writing, the narrator points to his own use of phraseology as a demonstration of prudent management of resources in the production of a text. If Wunschloses Unglück turns to the stock phrases that its protagonist, the mother, had no recourse against, it does so not without reason or 
simply because of their mysterious attraction, but because of contradictory motivations: they represent the primary target of criticism, all the while helping the narrator to deal with the problem of writing in a context of scarcity.

The secondary literature has often pointed out how the narrator of Wunschloses Unglïck remains attached to the phraseology, the insidious effects of which he sets out to criticize. And yet critics have neglected the detailed discourse on household management and labor by which the narrator negotiates the problem, and hence they have overlooked the novella's ongoing endeavor to connect the thematic focus on socio-economic issues and the formal concern of constructing a narrative. The issue of economy does not only dominate the mother's existence, but pervades the production of a biographical account and explains the reliance on the "Formelvorrat" that is also criticized. It is difficult to say, however, whether this extended reflection on the problem of writing within the text constitutes an elaborate and perhaps even specious justification of linguistic complicity, or if it amounts to an admission of failure.

The mother in Wunschloses Unglück is silenced. Or she is imprisoned in the household sphere, forced to deal with endlessly recurrent necessities, and when she speaks she does little more than adhere to the guidelines of the scripted gregariousness that underpins the spurious social harmony. Only rarely does her life transcend the daily practice of survival, and towards the end, as she succumbs to accumulating physical ailments and suffers a nervous breakdown, the narrator even notes the onset of a bestialization. He observes her "fleischgewordene animalische Verlassenheit," as if she had finally dropped out of the community of speaking humans and become a sample of "mere life" (77). ${ }^{16}$ The literary work that reconstructs and publicizes this process cannot 
so easily recover and release the mother's authentic voice. Indeed, the problem of an imposed speechlessness is not successfully remedied by the text but rather extends into it: the narrator has at his disposal no other language than the one that curtailed the mother's existence. In the text, the repeated insertion of regulatory phrases is even defended on the grounds of the need to economize. The problem of representation - the difficult and possibly self-defeating task of giving voice to the silenced - is thus reformulated as a problem of scarcity. This move does have the character of an excuse, for it converts the problem of complicity with a repressive idiom into the apparently contingent difficulty of temporarily insufficient resources. If he only had a more time and energy, the narrator seems to say, things would be different.

At the same time, the focus on the economy of writing inscribes the mother's predicament into the precarious or even failed attempt to represent her. The dominant feature of the mother's life - never-ending household management - becomes the dominant feature of the writing process, to indicate that writing too can be governed by inescapable necessities. A life circumscribed by the borders of the household is translated into literature, but by a text that systematically treats writing as a restricted household practice. Wunschloses Unglïck may not be able to endow the mother with a voice she never had, but through attention to the pressures under which she suffered, and through the figuration of the writing process in terms of analogous pressures, it tries to make her silence legible by putting its own failure on display.

\footnotetext{
${ }^{1}$ Gayatri Chakravorty Spivak's essay "Can the Subaltern Speak?" is a particularly probing inquiry into the issue of representing the underprivileged and excluded. In her analysis of how "Western intellectual production is [. . . complicit with Western
} 
international economic interest" (271), Spivak devotes critical attention to precisely those theorists who try to evade the problem of representation by claiming to vacate their place for a supposedly authentic non-Western voice, or "the first-world intellectual masquerading as the absent nonrepresentor who lets the oppressed speak for themselves" (292). In other words, Spivak studies how ethnocentric ideals of the "authenticity of the Other" continue to influence attempts to cast off ethnocentrism. This leads her to call for more analytical work on "the mechanics of the constitution of the Other" that operate within benevolent emancipatory projects (294, Spivak's emphasis).

${ }^{2}$ In the most recent installment in his polemics against the alleged demonization of Serbia by Western media, Die Tablas von Daimiel, Handke presents himself as an author in spontaneous communion with figures such as stranded refuges, who have come to inhabit neglected and desolate zones far from the nodes of commercial and political power. By now it is an established topos of German feuilletons that Handke's attachment to Serbia derives from his preference for the peripheral and the anachronistic; spaces not yet or no longer colonized and organized by a culture that takes pride in its hypermodernity. For an interpretation along these lines, see for instance Matthias Kamann's review "Konsequentes Dichtertum."

${ }^{3}$ Previous commentators have highlighted this problem of linguistic complicity in Wunschloses Unglück. In a brief critical summary of the novella, Scott Abbott writes that where "she [the mother] finds little recourse against the ready formulations in which a rural Austrian woman lived her life [...], the writer must turn to stock forms and ideas as well” (408). In an early book on Handke, to name another example, Rainer Nägele and Renate Voris note that the narrator of Wunschloses Unglück must write "in derselben Sprache, deren ideologisches Potential er freilegen möchte" (60). Stephan K. Schindler makes a similar point in his article, remarking that "er [the narrator] verfügt über keine Sprache, die sich außerhalb der diskursiven (Re)produktion von Geschlechtsidentitäten befindet" (42). This observation has not lost its appeal. Delivering a speech on Handke at the occasion of a ceremony to his honor at the University of Klagenfurt in 2002, Klaus Aumann declares that the novella "ist zugleich der gültige Versuch, die Schwierigkeiten zu beschreiben, die der Erzählung eines Frauenlebens entgegenstehen, das durch die gängigen Sprachformeln und Redensarten [...] verstellt ist” (240). Despite this broad consensus on the central obstacle to writing, the secondary literature does not include a detailed analysis of how this problem is reflected in the text itself.

${ }^{4}$ In his study of the painter Francis Bacon, Gilles Deleuze has formulated a similar experience with regards to painting: it is always "invaded and besieged by photographs and clichés that are already lodged on the canvas before the painter even begins to work. In fact, it would be a mistake to think that the painter works on a white and virgin surface. The entire surface is already invested virtually with all kinds of clichés, which the painter will have to break with" (10-11).

${ }^{5}$ While we tend to equate scarcity with the lack of adequate pecuniary means, one can also speak of scarcity of time and attention. In his Soziologie der Knappheit, for instance, Bálint Balla speaks of the scarcity of time: "Der Begriff der Zeitknappheit bezieht sich auf die Defizite zwischen der zur Befriedigung von Bedürfnissen, zur Verwirklichung von angesrebten Zielen erforderlichen Zeit einerseits und der jeweils tatsächlich verfügbaren Zeit andererseits" (26, Balla's emphasis). 
${ }^{6}$ This is a thesis propounded by, for instance, Matthias Konzett: with the insertion of the detached newspaper report, "Handke foregrounds mostly the euphemistic structure of media language, media's factually and situationally removed language, that belittles the loss of an individual life" (45).

${ }^{7}$ In her work The Human Condition, Hannah Arendt emphasizes the necessarily cyclical movement of all laboring activity: "laboring always moves in the same circle, which is prescribed by the biological process of the living organism and the end of its 'toil and trouble' comes only with the death of this organism" (98, Arendt's emphasis).

${ }^{8}$ In his essay "Trauer und Melancholie," Sigmund Freud asks "Worin besteht nun die Arbeit, welche die Trauer leistet?" suggesting that the withdrawal of libidinal investment after the death of a loved object requires a strenuous mental effort (430).

${ }^{9}$ The mother's exasperation with labor as a "Teufelskreis" of cleaning up and putting things in order can be compared with Arendt's observations regarding the cyclical character of laboring: "the daily fight in which the human body is engaged to keep the world clean and prevent its decay bears little resemblance to heroic deeds; [...] what makes the effort painful is not danger but its relentless repetition" (101).

${ }^{10}$ The limited or doubtful therapeutic value of the writing process is discussed by Regina Kreyenberger and Gudrun Lipjes-Türr: "Für die Dauer des Arbeitsprozesses schien es so, als gehörten sie der Vergangenheit an, als gelänge auf dem Weg literarischschöpferischer Objektivierung des eigenen Lebens auch dessen Bewältigung [...] Doch diese Hoffnung zerschlägt sich nach und nach durch die stete Wiederkehr der Angstzustände" (140).

${ }^{11}$ Cecile Cazort Zorach claims that the Dylan quotation "points to the vacuity of the time intervening between a person's birth and his death" (489). The narrator's mother is trapped in senseless routines from childhood into her adult years and hence the expression "busy dying" perfectly "sums up the plight of the Austrian housewife whose story is told in Wunschloses Unglück" (489).

${ }^{12}$ Stephan K. Schindler provides trenchant commentary on this aspect of the novella: "Diese Durchdringung der kleinbürgerlichen Familie mit den Normen 'Ordnung,' 'Tugend' und 'Sauberkeit' ist die vielleicht subtilste Art patriarchalischer Herrschaft, denn so wird die sozial bedingte Misere des Kleinbürgers zur moralischen Schuld der unordentlichen Hausfrau und Mutter" (50).

${ }^{13}$ Alexis de Tocqueville's study of democracy in America discusses the influence of the general fear of social sanctions upon the formation of opinions, beliefs, and desires. For a lucid reconstruction of Tocqueville's observations of multiple mechanisms of conformity, see Jon Elster's analysis in his Political Psychology (180-81).

${ }^{14}$ George Orwell's essay "Politics and the English Language" is a famous statement on the use of phrases as a means to save effort. However, the discussion of the social and economic functions of the phrase above is informed by a recent study on the survival of opinion diversity in communication networks of varying density, conducted by Robert Huckfeldt, Paul E. Johnson, and John Sprague. Political disagreement, they maintain, is unlikely in dense groups of interdependent citizens because of people's tendency to avoid conflict by adopting prevalent viewpoints, and to make use of the already formed opinions of others as a device to reduce effort. The diversity of opinions can easily 
dwindle within societies because of citizens' conflict avoidance and cost consciousness (7-8).

${ }^{15}$ According to Matthias Konzett, Handke's understanding of literature includes "attempts to reach beyond 'dead' meaning and to revitalize the expressive potential of literary discourse." He therefore seeks to "overcome sedimentary forms of cultural articulation such as rigid patterns and linguistic habits" (43). In Wunschloses Unglück, however, the narrator's deployment of these patterns and habits is subject to a more complex problematic of shortage.

${ }^{16}$ Giorgio Agamben has famously analyzed the production of life-forms deprived of communication in the death camps of totalitarian regimes, the site where the political rule over mere life emerges most starkly in the modern age. His discussion might seem absolutely unconnected with Handke's reflections of "Haushalten," but they are not. In a recent article on the Aristotelian concepts that figure prominently or even organize the current debate on the biopolitical paradigm, the most extreme example of which is the totalitarian camp, Malcolm Bull notes that the household or the oikos defined as the space were the basic necessities of life are tended to constitutes a "middle ground" between the silent life of animals and the life of communication in the polis (18). Following Hannah Arendt, Bull claims that modernity is characterized by an increasing political attention to this intermediary space, to the point at which modern societies are pictured as a kind of national households. To speak with Arendt, the "activities connected with sheer survival [household activities such as production and consumption] are permitted to appear in public" (Arendt 46). This politicization of the economic has a dual character: those who populate this sphere (women, laborers) are given place in the public thanks to the efforts of emancipatory movements, but the regimes of governance also increasingly take reproduction and labor as their objects of administration and intervention. The project of Wunschloses Unglück is consonant with the dual politicization of the household sphere in modernity. The novella spotlights the situation of the mother locked into the familial sphere - it brings (literary and political) attention to a life hid away. At the same time, it conceptualizes its activity in economic terms, as if writing would be another practice governed by the dictates of the household.

\section{Works Cited:}

Abbott, Scott. "Wunschloses Unglück." Encyclopedia of German Literature. Ed. Matthias Konzett. Vol. 1. London: Fitzroy Dearborn, 2000. 407-8.

Aumann, Klaus. "Peter Handkes Poetik der Begriffsstutzigkeit.” Peter Handke: Poesie der Ränder. Ed. Klaus Aumann, Fabjan Hafner, and Karl Wagner. Vienna: Böhlau, 2006. 239-51.

Arendt, Hannah. The Human Condition. Chicago: The U of Chicago P, 1958.

Balla, Bálint. Soziologie der Knappheit: Zum Verständnis individueller und gesellschaftlicher Mängelzustände. Stuttgart: Ferdinand Enke, 1978

Benjamin, Walter. "Karl Kraus." Gesammelte Schriften. Ed. Rolf Tiedemann and 
Hermann Schweppenhäuser. Vol. II.1. Frankfurt am Main: Suhrkamp, 1977. 33467.

Bewes, Timothy. "Shame, Ventriloquy, and the Problem of the Cliché in Caryl Phillips." Cultural Critique 63 (2006): 33-60.

Bull, Malcolm. "Vectors of the Biopolitical." New Left Review 45 (May-June 2007): 725.

Cazort Zorach, Cecile. "Freedom and Remembrance: The Language of Biography in Peter Handke's Wunschloses Unglück." The German Quarterly 52.4 (1979): 486502.

Deleuze, Gilles. Francis Bacon: The Logic of Sensation. Trans. Daniel W. Smith. London: Continuum, 2003.

Egner, Erich. "Haushalt." Handwörterbuch der Sozialwissenschaften. Ed. Erwin v. Beckerath, et al. Vol. 5. Stuttgart: Gustav Fischer, 1956. 65-70.

Elster, Jon. Political Psychology. Cambridge: Cambridge UP, 1993.

Freud, Sigmund. "Trauer und Melancholie." Gesammelte Werke. Ed. Anna Freud, et al. Vol. 10. Frankfurt am Main: S. Fischer, 1946. 428-46.

Green, Penelope. "Saying Yes to Mess.” New York Times Thursday Dec. 21 2006: F1+. Handke, Peter. Wunschloses Unglück: Erzählung. 1972. Frankfurt am Main: Suhrkamp, 1974.

. Die Tablas von Daimiel: Ein Umwegenzeugenbericht zum Prozeß gegen Slobodan Milosevic. Frankfurt am Main: Suhrkamp, 2006.

Huckfeldt, Robert, Paul E. Johnson, and John Sprague. Political Disagreement: The Survival of Diverse Opinions within Communication Networks. Cambridge: Cambridge UP, 2004.

Kamann, Matthias. “Konsequentes Dichtertum.” Die Welt Tuesday May 302006.

Konzett, Matthias. "Cultural Amnesia and the Banality of Human Tragedy: Peter Handke's Wunschloses Unglück and its Postideological Aesthetics." The Germanic Review 70.2 (1995): 42-50.

Kreyenberg, Regina, and Gudrun Lipjes-Türr. "Peter Handke: Wunschloses Unglück." Erzählen, Erinnern: Deutsche Prosa der Gegenwart. Ed. Herbert Kaiser and Gerhard Köpf. Frankfurt am Main: Moritz Diesterweg, 1992. 125-48.

Nägele, Rainer. "Peter Handke: Wunschloses Unglück (1972)." Deutsche Romane des 20. Jahrhunderts: Neue Interpretationen. Ed. Paul Michael Lützeler. Königstein: Athenäum, 1983.388-402.

Nägele, Rainer, and Renate Voris. Peter Handke. Munich: C. H. Beck, 1978.

Orwell, George. "Politics and the English Language." Complete Works. Ed. Peter Davidson. Vol. 17. London: Secker \& Warburg, 1998. 421-30.

Robbins, Lionel. An Essay on the Nature and Significance of Economic Science. London: MacMillan, 1945.

Schindler, Stephan K. "Der Nationalsozialismus als Bruch mit dem alltäglichen Faschismus: Maria Handkes typisiertes Frauenleben in "Wunschloses Unglück." Germanic Studies Review 19.1 (1996): 41-59.

Spivak, Gayatri Chakravorty. "Can the Subaltern Speak?" Marxism and the Interpretation of Culture. Ed. Cary Nelson and Lawrence Grossberg. Urbana: U of Illinois P, 1988. 271-313. 
Varsava, Jerry A. “Auto-Bio-Graphy as Metafiction: Peter Handke's A Sorrow Beyond Dreams." Clio 14.2 (1985): 119-35. 